Chirurgia (2019) 114: 103-108

No. 1, January - February

Copyright $@$ Celsius

http://dx.doi.org/10.21614/chirurgia.114.1.103

\title{
Single Supraclavicular Transverse Incision for Radical Neck Dissections
}

\section{Andy Petroianu}

Department of Surgery of the Medical School of the Federal University of Minas Gerais, Brazil

Corresponding author:

Professor Andy Petroianu

Avenida Afonso Pena, 1626 - apto. 1901

Belo Horizonte, MG 30130-005, Brazil

TEL. / FAX : 55-31-3274-7744

$55-31-98884-9192$

E-mail : petroian@gmail.com

\section{Rezumat}

Incizie transversală supraclaviculară unică pentru disecții ganglionare radicale

Introducere: Descrierea linfadenectomiei cervicale radicalã unilaterale şi respectiv bilaterale modificate care oferã acces la glanda tiroidã şi la toate stațile limfoganglionare ale gâtului printr-o incizie supraclavicularã transversã unicã.

Metodã: Limfadenectomia cervicalã radicalã uni-/bilateralã modificatã prin incizie supraclavicularã transversã unicã a fost efectuatã la 10 pacienți cu dianosticul de carcinom tiroidian sau respectiv labial. Toate nodurile limfatice cervicale anteriorioare şi laterale au fost rezecate în bloc cu tesutul fibro-lardaceu din vecinãtate, prezervând atât ambii muşchi sternocleidomastoidieni, cât şi ambele vene jugulare interne. În cazurile de carcinom tiroidian $\mathrm{s}^{-a}$ practicat tiroidectomie totalã în cursul aceleiaşi intervenții chirurgicale.

Rezultate: Aceastã procedurã chirurgicalã şi-a demonstrat fezabilitatea la toți pacienții, în condițile respectãrii principiilor oncologice. $\mathrm{Nu}$ s-au înregistrat complicații intra-/postoperatorii. Concluzii: Incizia supraclavicularã transversã unicã permite expunerea adecvatã a tuturor nodurilor limfatice cervicale, diminuând la minim riscul de complicații legate de incizie cât şi riscul de lezare a tesuturilor. Aceastã incizie este indicatã în cazurile de linfadenectomie radicalã cervicalã însã poate fi practicatã şi în cazurile în care sunt efectuate alte proceduri chirurgicale la nivel cervical.

Cuvinte cheie: limfadenectomie cervicalã, incizie transversã unicã, linfadenectomie cervicalã modificatã, vindecare cosmeticã 


\section{Abstract}

Background \& Aims: To describe unilateral and bilateral modified radical neck dissections with access to the thyroid gland and all neck lymph node levels through a single supraclavicular transverse incision.

Methods: Ten patients with thyroid or lip carcinomas were submitted to unilateral or bilateral neck dissection through a transverse supraclavicular neck incision. All anterior and lateral neck lymph nodes associated with surrounding fibrofatty tissue were dissected and removed, preserving both sternocleidomastoid muscles and internal jugular veins. Patients with thyroid carcinoma were also submitted to a total thyroidectomy during the same procedure.

Results: This surgery was feasible in all patients, preserving oncological principles with no adverse event.

Conclusions: A single supraclavicular transverse incision allows adequate access to all levels of the neck lymph nodes, minimises the risk of tissue breakdown and scar disorder, with good cosmetic results. This incision is indicated for radical lymphadenectomy and may be combined with other neck surgeries.

Key words: neck dissection, single transverse incision, modified neck lymphadenectomy, head and neck surgery, cosmetic healing

\section{Introduction}

Therapeutic neck dissection is recommended in patients with head and neck cancer and clinically evident involvement of the neck lymph nodes. The most common procedure is Mac Fee radical neck dissection, which is usually performed through an extended collar incision $3 \mathrm{~cm}$ above the clavicle extending to the posterior edge of the sternocleidomastoid muscle, combined with a second parallel transverse middle neck incision (1). Other neck approach options are unaesthetic vertical incisions, such as Hayes Martin and J incisions, which provide excellent surgical exposure at the expense of crossing Langer's tension lines, and may cause scar hypertrophy and stretching, and can lead to flap necrosis owing to ischemia (2-8). Any incision must afford the surgeon the flexibility to change the course of the operation, depending on the intraoperative findings, while allowing for optimal exposure of the operative site, as well as enable a rapid, safe, and oncologically complete procedure, whenever possible, with good aesthetic results $(9,10)$.

The aim of this study was to describe unilateral and bilateral modified radical neck dissections with access to the thyroid gland and all neck lymph node levels through a single supraclavicular transverse incision.

\section{Methods}

This study was a prospective audit of ten treated patients who required unilateral (7 patients: 5 left side and 2 right side) and bilateral (3 patients) modified neck dissections for $8 \mathrm{~N} 1 \mathrm{~b}$-stage-thyroid (5 papillary and 3 follicular) carcinomas with neck disease (8 patients) and left side lower-lip squamous-cell carcinoma (2 patients). The maximum follow ${ }^{-}$ up was of 46 months, with a minimum of 14 months.

\section{Surgical Procedure}

Under general anesthesia, the patient was placed in supine position, with the anterior neck slightly extended. A nasotracheal intubation was used in the two patients with lip cancer and neck metastases.

Around a $12 \mathrm{~cm}$ (unilateral dissection) or a circa $15 \mathrm{~cm}$ (bilateral dissection) transverse incision was performed on the upper board of both clavicles. The incision extended through the platysma, but not deeper (Fig. 1 A). 
The subplatysmal flap was elevated until it reached the lower board of the submandibular gland and mastoid process of the temporal bone in order to create sufficient working space (Fig. 1 B). During this process, the flap was retracted and maintained by the surgical assistant. The neck dissection was performed under direct vision, according with the welldefined standard steps of the modified neck lymphadenectomy, as follows.

At the beginning, the medial border of the sternocleidomastoid muscle (SCM), together with its fascia, was dissected from their sternal origin to their mastoidal insertion. The muscle lateral border was then dissected from the clavicular origin to its insertion, and was medially pulled to expose the omohyoid muscle, whose interventral tendon was sectioned. The sternothyroid and sternohyoid muscles were medially retracted to expose the lateral neck compartment.

The medial and lateral borders of the SCM were mobilized, and the common carotid artery (CCA), the internal jugular vein (IJV) and the vagus nerve were dissected. The IJV was retracted medially and the SCM laterally in order to identify and preserve the spinal accessory nerve at approximately $1 \mathrm{~cm}$ above Erb's point. Thereafter, the lymph nodes and the surrounding fibrofatty tissues were dissected. The anterior and the medium scalene muscles, as well as the phrenic nerve and the cervical plexus, were exposed. The upward dissection included levels I to VI lymph node chains, the brachial plexus and the phrenic nerve. The dissection later extended beyond the anterior margin of the trapezius muscle.

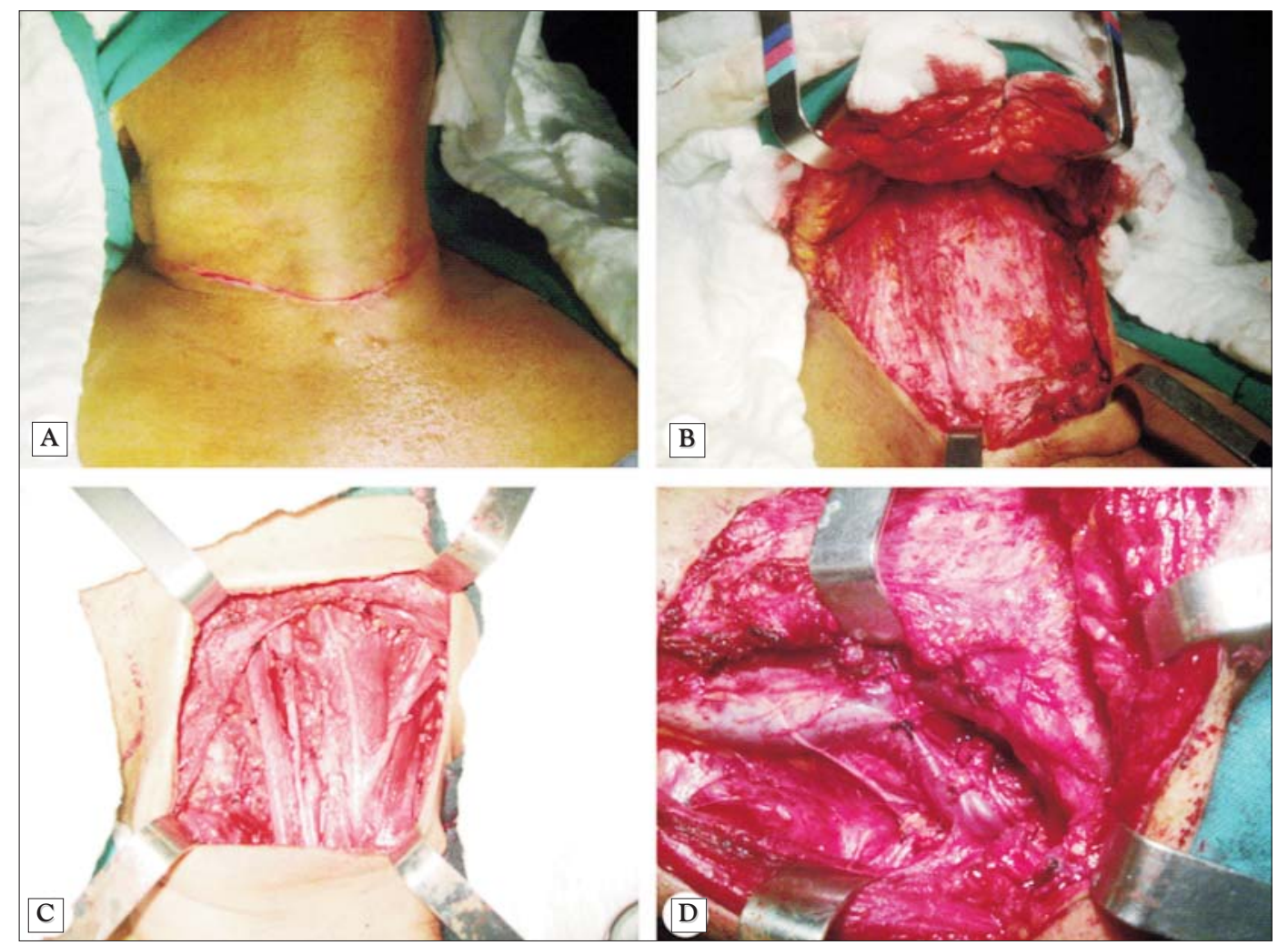

Figure 1. Surgical view of a single supraclavicular transverse incision for unilateral or bilateral neck lymphadenectomy. A - Supraclavicular neck incision. B - The skin and platysma flap lifting. C - Unilateral neck dissection showing the preservation of the sternocleidomastoid muscle and internal jugular vein. D - Bilateral modified neck dissection after removing all lymph nodes and their surrounding fibrofatty tissues, but preserving muscles, vessels and nerves. 
The dissection included the inferior pole of the parotid gland and continued along the medial border of the SCM muscle. After identification of the posterior belly of the digastric muscle, the SCM muscle was retracted upwardly and medially to dissect the level IIB lymph nodes. The mandibular branch of the facial nerve, the facial artery and the facial vein were identified under direct vision and preserved. The hypoglossal nerve was identified at the level of the CCA bifurcation and was preserved. Dissection was concluded and the specimen including all lymph nodes and surrounding tissues was removed (Fig. $1 C, D$ ).

For eight patients, the neck lymphadenectomy was associated with a total thyroidectomy, and no adversity occurred in all ten cases. A closed suction drain was unilaterally or bilaterally inserted below the hairline. The subcutaneous tissue and the skin were closed with subcutaneous and intradermic running absorbable thread sutures.

\section{Results}

This procedure was successfully carried out in all ten patients. Mean total operative time ranged from 200 to 340 minutes, and no significant blood loss occurred. No postoperative hemorrhage or hematoma, skin damage, infection or any other complication was observed. Approximately one week later, when the daily volume of drainage was less than $30 \mathrm{~mL}$, the closed suction drain was withdrawn. Immediately after drain removal, the patients were released from the hospital. The cosmetic results were good and all patients were satisfied with the surgical result and neck aspect.

Little fluid collection was observed in eight patients after the drain removal, but none of them required its surgical drainage or aspiration. Spontaneous leak of this fluid through the incision occurred in six patients during the early two postoperative weeks, and the remaining fluid was spontaneously absorbed in one month.

The pathology results confirmed the cancer in all patients and eight of them presented lymph node metastases.

All patients are still under our medical control and no complication has been verified during the 14 to 46 months follow-up. Recurrence of the tumours or new neck and distant metastases were not detected in any of the ten patients. The surgical oncological principles were followed, and the patients were referred to oncologists and endocrinologists for adjuvant therapy.

\section{Discussion}

Neck lymphadenectomy, based on Halsted and Kocher principles, has become widely accepted as a necessary part of the treatment of head and neck cancers. A variety of skin incisions have been introduced to provide a suitable approach to the cervical lymphatics, from Crile 1905 to the more recent endoscopic, video-assisted and remote access robotic neck surgeries $(1,4,6,11-14)$. However, no specific incision or combination of surgical approaches has received a general acceptance as a standard model for neck lymph node dissection $(4,11)$. Neck dissection through a single transverse incision in the middle of the neck has been described since 1957. The only original surgical technique of this article is the supraclavicular location of the incision, which was not found in the consulted literature related to the neck radical total lymphadenectomy $(8,15-20)$.

Modified neck dissection, preserving the sternocleidomastoid muscle, spinal accessory nerve and internal jugular vein, is recommended whenever possible. The lower postoperative adverse effects with better cosmetic results and without breaking from the oncological principles justify the preservation of these structures (7). In terms of better surgical results, in cases of thyroid carcinomas with lateral neck node metastases, concomitant radical neck lymphadenectomy through the same supraclavicular transverse incision should be considered $(11,13)$.

Previous reports on endoscopic lateral neck dissection have mainly adopted the videoassisted approach in the neck. However, the 
working space of these approaches is rather small, which may result in limitations of instrumentation and risks to oncological principles (5).

The management of metastatic disease in the neck has changed considerably over the past few decades. With a better understanding of the patterns of lymph node metastases, and a better understanding of the importance of prognostic factors, such as perineural invasion, the preservation of non-lymphatic structures has led to less postoperative complications, with an improved quality of life and functional outcomes (20). The extended neck dissection has been replaced by modified total neck lymphadenectomy, resulting in the preservation of vessels, nerves and muscles.

The uneventful postoperative follow-up reinforces the efficacy of the neck radical dissection through a single supraclavicular incision. We could not find any disadvantage of this incision approach considering that the surgical procedure is not different or more difficult than either performed through other neck incisions. No special surgical skill or experience is necessary for a head and neck surgeon to perform the lymphadenectomy through a single incision.

\section{Conclusions}

A single supraclavicular transverse incision allows adequate access to all levels of the neck lymph nodes, and minimises the risk of tissue breakdown and scar disorder, with good cosmetic results. This incision is recommended for total unilateral or bilateral lymphadenectomy to treat head and neck cancers, and may be associated with other surgical procedures, such as total thyroidectomy, preserving all oncological principles.

\section{Acknowledgments}

The authors gratefully thank the Research Support Foundation of the State of Minas Gerais (FAPEMIG), the National Council for Scientific and Technological Development $(\mathrm{CNPq})$ and the Dean's Office for Research
(Pró-reitoria de Pesquisa) at UFMG for their financial support.

\section{Ethics approval and consent to participate}

This procedure was previously approved by the Ethics Committee for Research of the Federal University of Minas Gerais (Reference CAAE2013-09543912.0.0000.5149).

\section{Competing Interests}

The author declares no competing interest with respect to this research, authorship and publication of this article. The author has no financial relationship with any organization.

\section{Funding}

No funding supported this work and publication.

\section{Author Contribution}

All surgical procedures, care of patients, analysis of surgical results, manuscript, submission for publication.

\section{References}

1. MacFee WF. Tranverse-incisions for neck dissections. Ann Surg. 1960;151:279-84.

2. Acar A, Dursun G, Aydin 0, Akbas Y. J incision in neck dissection. J Laryngol Otol. 1998;112(1):55-60.

3. Kademani D, Dierks EJ. A straight-line incision for neck dissection: technical note. J Oral Maxillofac Surg. 2005;63(4):563-5.

4. Kitagawa W, Shimizu K, Akasu H, Tanaka S. Endoscopic neck surgery with lymph node dissection for papillary carcinoma of the thyroid using a totally gasless anterior neck skin lifting method. J Am Coll Surg. 2003;196(6):990-4.

5. Li Z, Wang P, Wang Y, Xu S, Cao L, Que R, et al. Endoscopic lateral neck dissection via breast approach for papillary thyroid carcinoma: a preliminary report. Surg Endosc. 2011;25(3):890-6. Epub 2010 Aug 24.

6. Martin H, Valle B, Ehrlich H. Cahan WG. Neck dissection. Cancer. 1951;4(3):441-99.

7. Patel KN, Shah JP. Neck dissection: past, present, future. Surg Oncol Clin N Am. 2005;14(3):461-77, vi.

8. Simo R, Nixon I, Tysome JR, Balfour, A Jeannon JP. Modified extended Kocher incision for total thyroidectomy with lateral compartment neck dissection. Clin Otolaryngol. 2012;37(5):395-8.

9. Appiani E, Delfino MC. Plastic incisions for radical neck tumors. Ann Plast Surg. 1984;13(4):335-52.

10. Petroianu A. Parotidectomy by periauricular incision. Otolaryngol Head Neck Surg. 2012;146(2):247-9. Epub 2011 Aug 22.

11. Byeon HK, Holsinger FC, Tufano RP, Chung HJ, Kim WS, Koh YW, et al. Robotic total thyroidectomy with modified radical neck dissection via unilateral retroauricular approach. Ann Surg Oncol. 
2014;21(12):3872-5.

12. Crile GW. Excision of cancer of head and neck with special reference to the plan of dissection based on 132 operations. J Am Med Assoc. 1906;47:1780-1786.

13. Kim WS, Lee HS, Kang SM, Hong HJ, Koh YW, Lee HY, et al. Feasibility of robot-assisted neck dissections via a transaxillary and retroauricular ("TARA") approach in head and neck cancer: preliminary results. Ann Surg Oncol. 2012;19(3):1009-17. Epub 2011 Nov 2.

14. Wu B, Ding Z, Fan Y, Deng X, Guo B, Kang J, et al. Video-assisted selective lateral neck dissection for papillary thyroid carcinoma. Langenbecks Arch Surg. 2013;398(3):395-401.

15. Attie JN. A single transverse incision for radical neck dissection. Surgery. 1957;41(3):498-502.

16. Becker GD. Extended single transverse neck incision for composite resections: an update of technique and results. Laryngoscope. 1984;94(5 Pt 1):605-7.

17. Myssiorek D, Becker GD. Extended single transverse neck incision for composite resections. J Surg Oncol. 1991;48(2):101-5.

18. Chagas JF, Pascoal MB, Aquino JL, Brandi LA Filho, Previtale EV, et al. Single transverse extended incision for radical neck dissection. Rev Col Bras Cir. 2016;43(4):270-5. English, Portuguese

19. Song CM, Ji YB, Kim IS, Lee JY, Kim DS, Tae K. Low transverse incision for lateral neck dissection in patients with papillary thyroid cancer. World J Surg Oncol. 2017;15(1):97.

20. Antohi N, Tibirna G, Suharski I, Huian C, Nae S, Stan V, et al. Gastro-omental free flap in oro/hypopharyngeal reconstruction after enlarged ablative surgery for advanced stage cancer. Chirurgia (Bucur). 2013;108(4):503-8. 